\title{
Seasonal growth of sprouts in introduced three plants under extra arid conditions of Southern Uzbekistan
}

\author{
Lutfullo Yoziev*, Shohista Samatova, and Muhayyo Buronova \\ Karshi state university, Karshi, Uzbekistan
}

\begin{abstract}
The article presents the results of the study of the growth dynamics of the sprouts of 52 woody plants, representing 19 genera from 5 families, of different geographical origin. In the conditions of Southern Uzbekistan, the growth of introduced species takes place in early, more favorable spring terms and is characterized by higher intensity. With the onset of the extreme period (early June), the vast majority of species stop growing. Most species studied have a short growth period. The strategy of adaptation of introduced plants is expressed in reduction of growth period and increase of its rate.
\end{abstract}

\section{Introduction}

Arbor flora of Southern Uzbekistan is not distinguished by the rich in species diversity and the high decorative properties of plants. It is possible to enrich the green assortment only by introducing new decorative plants. Surveys have shown that 215 species, 4 forms and 5 hybrids grow in arboretums, parks and urban plantations - a total of 224 species of introduced trees, representing 113 genera from 52 families. The gymnosperms are represented by 18 species and 2 decorative forms belonging to 12 species from 6 families. The angiosperms are represented by 197 species, 2 forms and 5 hybrids. Introduced species come from 8 floristic regions of the globe. The main mass is from the East Asian region, then from the Circumboreal, Iran-Turan and Atlantic-North American regions [1].

The purpose of the works - to reveal the degree of adaptation of plants to the new extreme conditions of the external environment of Southern Uzbekistan on the basis of long term researches on the growth of introduced species and determine the most promising centers for introducing of woods exotics.

\section{Experimental}

In the research 52 species of wood plants introduced to South Uzbekistan, having different origins and taxonomy.

The territory of Southern Uzbekistan covers Kashkadarya and Surkhandarya regions, occupying the south-western part of the Pamir-Alay mountain system and the lowland Karshinsky steppe. The western majority of the Kashkadarya region is occupied by extensive plain spaces. To the east and northeast the territory gradually increases and passes into foothills and then - into mountain areas. Surkhandarya region occupies the southernmost position within Uzbekistan, touching along its entire eastern border with Tajikistan. In the southern part, closer to Amudarya, on the banks of Surkhandarya there are significant sandy areas [2].

The growing period in the region lasts 290-300 days. The annual amount of precipitation is the least in the southern lowland areas and reaches $130-250 \mathrm{~mm}$. During the height of summer, temperatures can reach very high limits. Temperature highs exceed $40-42^{\circ} \mathrm{C}$ each year. In lowland and pre-mountain parts the absolute maximum temperature exceeds $46-48^{\circ} \mathrm{C}$, reaching in Termez and Shirabad almost $50^{\circ} \mathrm{C}$ - the record value for Uzbekistan [3]. On the territory of the region there are two groups of soil regions: a belt of grey earth and a zone of desert soils. In the alluvial conditions of this region there are developed soils of the type of grey, represented by two subtypes - typical and light grey soils, in the second types of desert soils: grey-brown, desert, sandy, superstition and taker soils with two subtypes - taker soils and takers [4].

Dynamics of sprout growth were studied according to the method of A.A. Molchanov, V.V. Smirnov [5], phonological observations - according to on L.C. Plotnikova [6], literature data on the origin of species are given according to "Trees and shrubs of the USSR" [7], plant names are specified according to S. K. Cherepanov's bulletin [8]. Variation statistics uses computer programs SNEDECOR [9].

\section{Results and discussion}

For studying the growth of lateral sprouts, the most richly represented genera were chosen first of all.

The features of seasonal growth of four species of Salix - S. daphnoides, S. alba, S. babylonica, S. longifolia and four species of Populus - P. bolleana, P. ariana, P. nigra, P. alba (Table I) were studied. The earliest start of growth is species for Salix babylonica - from March 5, S.

\footnotetext{
*Corresponding author: yoziyevl@mail.ru
} 
alba begins growing in mid-March, the rest of the species - in late March, and Populus alba - at the begin of April.

Growth cessation takes place at different times. The four species of named genera stop growing in May, the two - in June, the other two species - in July.

For the species finishing growth in May, the main growth of sprouts occurs in April (50.2-62.3), for the species with a long growth period - in May. The latter tend to produce more gain and feature smooth growth during the growing period. The growth in short-growth species is $21.4-27.8 \mathrm{~cm}$, while in long-growth species it is several times higher.

The duration of growth and the magnitude of current growth in members of the type Populus are very close to each other, while in Salix species these figures are very different.

The example of conifer introducents shows that the duration of growth of sprouts is mainly a generic feature, whereas the intensity of growth is feature a species [10]. The data we have obtained suggest that in deciduous, this pattern persists in not all the genera.

In the conditions of Southern Uzbekistan, the most introduced species of Quercus begin to grow in late March, some in early April. Growth cessation and sprout laying occurs in different species at different times. Q. Mongolica is the first to complete the growth - at the end of April, the rest of the species (except species of Caucasian origin) cease in the first decade of May (Table I).

In all species, the main growth sprouts occurs in April (55.4-98.4). Growth graph is characterized by singlepeakscrew curves. The species we have studied come from different climatic areas, but they are not dramatically different in growth timing, duration, rate of current growth of sprouts. At the same time, the smallest growth gain (and shorter growth duration) was observed in the Mediterranean species Q. suber, the largest one - in the Crimean and Caucasus species (Q. castaneifolia, Q. pubescens).

Of all species in the genus Quercus, secondary growth gain is seen only in Q. castaneifolia. The first growth gain is completed at the end of April and during this period $86.1 \%$ of the annual gain is generated. In mid-June, plants start again growing, which lasts for an average of 2 weeks. At the same time, we did not observe the multiple growth of Q. robur, noted by other authors: in Tashkent [11] and in Minsk [12].

In general, the species of the genus Quercus in our conditions are characterized by a short period of growth of sprouts (33-38 days).

Unlike previous species, representatives of Fagaceae vary widely among themselves in both of duration and rates of growth and the magnitude of sprout growth gain.

Growth of most species from Fabaceae family begins at the end of March, and of the rest - in the first decade of April (Table 2).

The cessation of growth also occurs at various times. The first to complete the growth is Gymnocladus dioicus (April 20), then - Claudrastis lutea, Caesalpinia gilliesii and Laburnum anagyroides - in the first decade of May. In the second decade of May, the growth of Cercis canadensis and Genista tincloria is stopped, in the third decade - Cercis siliquastrum, Amorpha fruticosa and Caragana turkestanica. Robinia pseudoacacia, Gleditsia triacanthos, and Sophora japonica finish growing in early June, Wisteria species in early July, Albizia julibrissin in late July, capturing the hottest period of vegetation. The most intense growth in species with a short growth period occurs in April, with an extended growth period in May. Having a long growth period, Albizia julibrissin and Wistrea sinensis differ in its smooth course.

The average annual growth varies from 11.2 to 116 $\mathrm{cm}$. Fabaceae are characterized by intense growth of yearlong sprouts.

In Acer species, the growth of sprouts in our conditions begins mainly in the II-III decades of March. Rising temperatures and heavy rainfall in April contribute to an intense growth of sprouts. The cessation of growth in A. negundo occurs in late April, in A. campestre, A. ginnala, A. ukurunduense, and A. saccharinum - in the first decade of May, in A. truncatum, and A. semenovii in the third decade of May (Table III). In the conditions of the Republic of Komi, four species of maple (Acer negundo, A. tataricum, A. ginnala and A. platanoides) also showed an accelerated growth and development rate [13].

The main growth in sprouts $(52.4-86.4 \%)$ in all species occurs in April. Current growth ranges from 6.75 $\mathrm{cm}$ (A. saccharium) to $34.8 \mathrm{~cm}$ (A. velutinum). The rest of the species occupy an intermediate position. Growth in all species is characterized by a single-peat curve. The exception is A. velutinum, which is of subtropical origin. This species has two increases in growth (Table III). This phenomenon is observed by other authors in other circumstances. G.N. Gordeeva notes that in the conditions of Hakassia the beginning of summer is dry (June - July), at the end of July - the beginning of August the rains begin, and many plants of arboretum start apical budding a new and begin growth [14]. Meanwhile, in the conditions of Southern Uzbekistan, the studied Acer species differ in a relatively short growth period (44-66 days), timed mainly in the spring period, when the humidity of the air and soil is quite high. Of the Fraxinus species (F. excelsior and F. angustifolia) are the first to begin growth - in the 2nd decade of March. In the third decade of March, growth begins in F. rhynchophylla, F. americana, F. pennsylvanica, and F. sogdiana. Later then all (in early April) F.velutina begins to grow (Table IV).

Stopping growth occurs almost in the same sequence as starting growth - species that started growth early tend to finish it earlier. The exception is the drought-tolerant species F. sogdiana, which differs from other species in a prolonged period of growth. 
Table 1. Growth of lateral sprouts of members of family Salicaceae Lindl. and of family Fagaceae A.Br.

\begin{tabular}{|c|c|c|c|c|c|c|c|c|c|c|}
\hline \multirow{3}{*}{ Species } & \multirow{3}{*}{$\begin{array}{c}\text { Geographical } \\
\text { origins }\end{array}$} & \multicolumn{3}{|c|}{ Growth of sprouts } & \multicolumn{6}{|c|}{ Gain } \\
\hline & & \multirow{2}{*}{$\begin{array}{c}\text { beginn } \\
\text { ing }\end{array}$} & \multirow[b]{2}{*}{ end } & \multirow{2}{*}{$\begin{array}{l}\text { long, } \\
\text { days }\end{array}$} & \multicolumn{5}{|c|}{ monthly, \% } & \multirow{2}{*}{$\begin{array}{c}\text { Annual, } \\
\mathrm{cm}\end{array}$} \\
\hline & & & & & III & IV & V & VI & VII & \\
\hline Salix daphnoides & Europe & 15.03 & 20.07 & 128 & 12.2 & 23.0 & 36.9 & 19.2 & 8.7 & $67.5 \pm 2.41$ \\
\hline S. alba & Europe & 16.03 & 05.06 & 82 & 18.5 & 36.6 & 42.2 & 2.7 & --- & $45.5 \pm 1.46$ \\
\hline S. babylonica & East Asia & 05.03 & 03.07 & 148 & 15.8 & 25.4 & 21.2 & 20.1 & 17.3 & $74.6 \pm 1.59$ \\
\hline S. longifolia & North America & 25.03 & 15.05 & 51 & 7.2 & 62.3 & 30.5 & $\begin{array}{ll}-- \\
\end{array}$ & $\begin{array}{ll}-- \\
\end{array}$ & $27.8 \pm 1.16$ \\
\hline Populous bolleana & Central Asia & 25.03 & 30.05 & 66 & 5.3 & 51.6 & 43.1 & --- & --- & $23.8 \pm 1.22$ \\
\hline P. areana & Central Asia & 25.03 & 30.05 & 66 & 4.8 & 53.6 & 41.6 & --- & $\begin{array}{ll}--- \\
\end{array}$ & $21.4 \pm 1.12$ \\
\hline P. nigra & Europe & 30.03 & 30.05 & 62 & 1.3 & 50.2 & 48.5 & --- & $\begin{array}{ll}--- \\
\end{array}$ & $23.7 \pm 1.33$ \\
\hline P. alba & Central Asia & 05.04 & 05.06 & 62 & $\begin{array}{ll}-- \\
-\end{array}$ & 44.0 & 52.5 & 3.5 & --- & $22.8 \pm 1.14$ \\
\hline Quercus suber & Mediterranean & 03.04 & 05.05 & 33 & --- & 97.7 & 2.3 & --- & --- & $10.3 \pm 0.97$ \\
\hline Q. robur & Europe & 31.03 & 05.05 & 36 & 1.0 & 98.4 & 0.6 & --- & --- & $18.9 \pm 2.82$ \\
\hline Q.r. f. fastigiata & Europe & 02.04 & 05.05 & 34 & --- & 93.9 & 6.1 & --- & --- & $20.5 \pm 1.15$ \\
\hline Q. castaneifolia & Crimea, Caucasus & 20.03 & 30.06 & $30+15$ & 15.0 & 71.1 & --- & 13.9 & $\begin{array}{ll}-- \\
-\end{array}$ & $20.1 \pm 2.81$ \\
\hline Q. petraea & Europe & 29.03 & 05.05 & 38 & 5.4 & 91.4 & 3.2 & $\begin{array}{ll}-- \\
-\end{array}$ & $\begin{array}{ll}-- \\
-\end{array}$ & $21.0 \pm 1.38$ \\
\hline Q. pubescens & Crimea, Caucasus & 01.04 & 15.05 & 45 & --- & 75.5 & 24.5 & --- & --- & $22.0 \pm 1.67$ \\
\hline Q. mongolica & Siberia & 21.03 & 25.04 & 36 & 20.8 & 79.2 & --- & --- & --- & $25.2 \pm 3.01$ \\
\hline Q. macrocarpa & North America & 30.03 & 05.05 & 37 & 2.2 & 96.3 & 1.5 & $\begin{array}{ll}-- \\
-\end{array}$ & --- & $18.9 \pm 1.46$ \\
\hline
\end{tabular}

In all Fraxinus species, the main increase in sprouts is observed in April. Their growth on the chart is characterized by a single-peak curve.

In general, Fraxinus species have a short period of sprout growth (35-55 days) and the largest annual increase. Among Ligustrum species, L. lucidum stands out, beginning growth last and ending it first. Consequently, the duration of the sprout growth period in this species is shortest (42 days). This species naturally grows in conditions where there is heavy rainfall during the summer period (Central China). In our conditions, the short period of sprout growth is due to apparently hot and dry weather. The remaining Ligustrum species are characterized by a long growth period and differ by a twoturn curve. The main growth in the species studied of this genus occurs in April.

Thus, these data suggest that the nature of the growth of sprouts in tree plants, its intensity and duration are significantly determined by the belonging of the species. Species of one genus have close growth rates. In the conditions of Southern Uzbekistan in most species intensive growth is timed mainly to the spring period, when the humidity of the air and soil is quite high. Dry and hot weather, beginning usually in the second half of May, contributes to the completion of growth in many species. In hot conditions, the growth of sprouts in plants is intense. The most intense growth of sprouts in species by a short period of growth is observed in April, with an elongated one in May.

\subsection{Features of the growth of introducents depending on their origin.}

The characteristics of the growth rhythm, its intensity and period duration are determined by the ecologicalbiological properties of the species due to their origin and geographical distribution.

It is advisable to compare the features of the growth of sprouts in the genera represented by the largest number of species. The growth data of the most fully represented genera - Salix, Populus, Quercus, Acer, Fraxinus are given in tables 1-4.

As a result, it was found that the longest period of growth have species from Crimea and the Caucasus. Thus, Pinus eldarica (164 days) and Taxus baccata (152 days), originating from the area, grow longest from conifers. Duration of growth period of sprouts of other species of conifers varies within 34-95 days.

Among Quercus species, the long growth period is also characterized by species from Crimea and the Caucasus - Q. castaneifolia and Q. pubescens (Table 1). The same pattern is observed in Pyrus species: the growth period duration of $\mathrm{P}$. hyrcana and $\mathrm{P}$. elaeagrifolia is 64 and 46 days, respectively, while in the European species $\mathrm{P}$. communis is 31 days.

There are 16 of family Fabaceae belonging to 13 species that have the longest growth period in Albizia julibrissin - 123 days (Table 2).

The genus Acer is represented by one species of Caucasian origin A. velutinum, also having the longest growth period compared to the rest of the species (Table 3). 
Among North American genera species, natural area of which is located in the southern areas (Gleditsia triacanthos), where the vegetative period lasts longer than of northern species, they grow longer time. The same pattern is observed in species of European origin.

Species from Siberia are characterized by an early onset and a short period of growth. Thus, Acer ginnala, A. ukurunduense, Quercus mongolica start growing well ahead of other species of the respective genera and feature a short growth period. This pattern has also been identified in other conditions [13].

According to L.G. Martynov [13], for example, Far Eastern species start growing two or three days earlier than European species. The end of the growth of sprouts in most species takes place at the end of June - the beginning of July. Duration of sprouts growth is 40-65 days.

The next place after the Caucasus species by the length of the sprout growth period is occupied by species from East Asia. Thus, of the 3 species of Morus species, East Asian species are characterized by a long growth period: M. alba - 103 days, M. nigra - 90, while M. rubra (North America) - 57 days.

From 16 species of family Fabaceae 's longest growth period, following Albizia julibrissin, is characterized by Wisteria sinensis; among Salix is S. babylonica (Table I). Of the 10 species of genus, Acer is second after A.velutinum. Among other species, there are also species with prolonged growth, especially thermopiles and relatively drought-tolerant species. Thus, Melia azedarach, M. toosendan grow 102-111 days.

In Mediterranean species - Quercus suber, Buxus sempervirens and Elaeagnus angustifolia - there was a short period of growth (Table 1). In local species, the longest period of growth was observed in droughtresistant species growing in floodplains and foothills. For Ulmus pumila pasteur it lasts 138 days, Fraxinus sogdiana - 55. In this regard, they are at the top of the other species of the genus we have studied.

Thus, the results of our research confirm the views of other authors that the characteristics of the growth of wood plants is largely determined by their origin and geographical distribution. The longest period of growth is distinguished by the species of Crimea and Caucasus (especially Gircan species), then East Asian (Central Chinese, North Chinese species) origin. Plants from Siberia and Mediterranean species have a short growth period. Consequently, in the new conditions, species originating from areas with close climatic indicators grow longer.

\subsection{Duration of the sprout growth period}

In the remaining 120 species, the length of the sprout growth period was determined by sprouting term in the early spring and laying them on one-year sprouts.

All studied ones (200 species), according to the duration of the growth period of sprouts, are divided into 4 groups (Fig. 1).

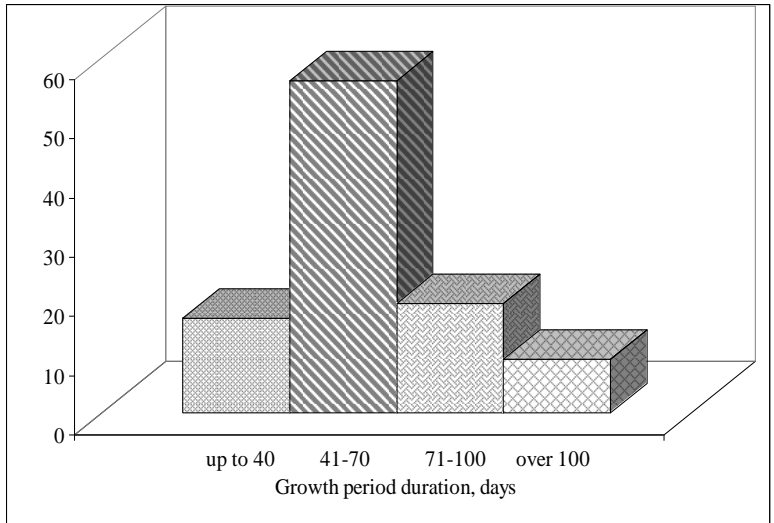

Fig 1. Distribution of Southern Uzbekistan 's introducents by growth duration

I. Species with a very short sprout growth period of 40 days - 33 species (16\%). This includes almost all species of Picea, Juglans, Quercus, Celtis, Sorbus, Tilia, Diospyros; from family Fabaceae - Gymnocladus dioicus, Cladrastis lutea and Caesalpinia gilliesii; as such Rhus typhina, Cotinus coggygria, Aesculus hippocastanum, Fraxinus americana and F. pennsylvanica.

II. Species with a short period of sprout growth - 4170 days. This includes 112 species (56\%). It is the largest group including the vast majority of species of large genera - Cupressus, Populus, Ribes, Malus, Pyrus, Crataegus, Spiraea, Acer, Fraxinus; as well as the main representatives of this. Fabaceae of the individual species are included a number of representatives like Maclura aurantiaca, Eucommia ulmoides, Mespilus germanica, Laurus nobilis.

III. Species with average sprout growth period (71100 days). This group combines 37 species $(18.5 \%)$ and is represented by Salix, Morus, Amelancher, Pyracanta, Chanomeles, Berberis, Platanus genera; as well as individual species - Sophora japanica, Gleditsia triacanthos, Platycladus orientalis, Taxodium distichum, Juniperus virginiana and other.

IV. Species with extended growth period - more than 100 days. This includes 18 species (9\%). Members of this group are mostly subtropical trees, shrubs and lians.

So, the predominant majority of studied species $(72 \%)$ in Southern Uzbekistan conditions have a very short (up to 40 days) or short (41-70 days) period of sprout growth.

\section{Conclusion}

Plant growth is a very reliable criterion for species adaptation, reflecting the bioecological features of species due to their taxonomy, origin, evolutionary history and climatic conditions of the introduced species.

An abundance of light and heat, the extended growing period ensures the rapid growth of wood introducents. The strategy of adaptation of introducents in our conditions is expressed in reduction of the period of growth and increase of its rate.

In the conditions of Southern Uzbekistan, the growth of sprouts of introducent takes place in early, more favorable spring terms and is characterized by higher 
intensity. With the onset of the extreme period (early June), the vast majority of species stop sprout growing.

Species from the Ancient Mediterranean region, the climatic conditions of which are close to those of Southern Uzbekistan, feel better and adapt easier. The same species have the longest growth. These are species from Crimea, Caucasus, East Asia and southern parts of North America.

The main limiting factor of the period of sprout growth in our conditions is high temperature and low humidity. Species living in wet conditions and in the boreal zone in our conditions give less growth gain, and their growth processes stop much earlier.

\section{References}

1. L.H. Yoziev, Experience of introduction of wood plants to South Uzbekistan, Tashkent: Fan (2001)

2. Atlas Uzbek SSR. Geomorphologic card, M.Tashkent: GUGK Office at SM of the USSR pp. 5859 (1982)

3. Agro-climatic bulletin, Tashkent: SARNIGMI publishing house (1990-1996)

4. S.A. Azimbayev, Soils of the southern part of Uzbekistan and their reclamation state, Tashkent: Fan (1991).
5. A.A. Molchanov, V.V. Smirnov, Method of studying the growth of wood plants, Moscow: Science, (1967)

6. L.C. Plotnikova, Method of phonological observations in botanical gardens SSR, Moscow, pp. 40-46 (1972)

7. Trees and shrubs of the USSR, T. I-VI. M.-L., Academy of Sciences of the USSR (1949-1962)

8. S. K Cherepanov, Vascular Plants of Russia and Neighboring States, Saint Petersburg: "Peace and Family-95" (1995)

9. O.D. Sorokin, Applied Statistics on Computer, Krasnoobsk: State Department of RPO SO RASKHN (2004)

10. N.V. Shkutko, "Biological bases of introduction of coniferous plants in Belarus," Avtoref. yew. doctor of biological sciences, Moscow (1984)

11. A.A. Mavzhudov, Dendrology of Uzbekistan. T. XIII, Tashkent: Fan, pp. 3-91 (1983)

12. T.F. Deryugina, Seasonal growth of hardwood rocks, Minsk: Science and Technology (1984)

13. L.G. Martynov, "Introduction of maple species in the Republic of Komi," News of Komi Scientific Center of Uro RAS, 32, pp. 25-32 (2017)

14. G.N. Gordeeva, "Seasonal rhythm of development of Tilia L. species in the arboretum of Hakassia," Mater. report XVIII International Scientific and Practical Conference, Problems of botany of Southern Siberia and Mongolia, Barnaul, pp. 575-579 (2019)

Table 2. Growth of lateral sprouts of members of family Fabaceae Lindl.

\begin{tabular}{|c|c|c|c|c|c|c|c|c|c|c|}
\hline \multirow{3}{*}{ Species } & \multirow{3}{*}{$\begin{array}{c}\text { Geographical } \\
\text { origins }\end{array}$} & \multicolumn{3}{|c|}{ Growth of sprouts } & \multicolumn{6}{|c|}{ Gain } \\
\hline & & \multirow{2}{*}{$\begin{array}{c}\text { begin- } \\
\text { ning }\end{array}$} & \multirow[b]{2}{*}{ end } & \multirow{2}{*}{$\begin{array}{l}\text { long, } \\
\text { days }\end{array}$} & \multicolumn{5}{|c|}{ monthly, \% } & \multirow[b]{2}{*}{ Annual, cm } \\
\hline & & & & & III & IV & $\mathrm{V}$ & VI & VII & \\
\hline Albizia julibrissin & Crimea, Caucasus & 30.03 & 30.07 & 123 & 1.2 & 25.0 & 27.5 & 24.0 & 22.3 & $43.0 \pm 1.71$ \\
\hline Cercis canadensis & North America & 01.04 & 20.05 & 50 & --- & 61.8 & 38.2 & --- & --- & $11.2 \pm 0.62$ \\
\hline C. siliquastrum & Mediterranean & 02.04 & 30.05 & 59 & --- & 54.5 & 45.5 & --- & --- & $33.0 \pm 1.20$ \\
\hline Caesalpinia gilliesii & South America & 10.04 & 10.05 & 31 & --- & 71.7 & 28.3 & --- & --- & $26.5 \pm 1.02$ \\
\hline Gleditsia triacanthos & North America & 24.03 & 05.06 & 74 & 5.2 & 44.3 & 46.0 & 4.5 & --- & $58.3 \pm 2.10$ \\
\hline G. caspica & Crimea, Caucasus & 31.04 & 20.07 & 112 & --- & 26.5 & 29.0 & 23.5 & 21.0 & $38.5 \pm 1.15$ \\
\hline Gymnocladus dioicus & North America & 25.03 & 20.04 & 27 & 24.0 & 76.0 & --- & --- & --- & $43.3 \pm 1.69$ \\
\hline Sophora japonica & East Asia & 29.03 & 10.06 & 74 & 1.7 & 43.9 & 48.3 & 6.1 & $\begin{array}{l}-- \\
--\end{array}$ & $51.6 \pm 1.92$ \\
\hline Cladrastis lutea & North America & 05.04 & 05.05 & 31 & --- & 86.2 & 13.8 & --- & --- & $32.3 \pm 1.10$ \\
\hline Genista tincloria & Europe & 04.04 & 16.05 & 43 & --- & 62.5 & 37.5 & --- & --- & $25.5 \pm 1.44$ \\
\hline $\begin{array}{l}\text { Laburnum } \\
\text { anagyroides }\end{array}$ & Europe & 25.03 & 10.05 & 47 & 16.8 & 65.0 & 18.2 & --- & --- & $40.8 \pm 1.93$ \\
\hline Amorpha fruticosa & North America & 10.04 & 30.05 & 51 & --- & 42.5 & 57.5 & --- & --- & $29.5 \pm 1.56$ \\
\hline Wisteria sinensis & East Asia & 30.03 & 07.07 & 100 & 1.3 & 30.2 & 34.4 & 29.0 & 5.1 & $116.0 \pm 6.01$ \\
\hline W. floribunda & East Asia & 10.04 & 05.07 & 87 & 1.0 & 29.5 & 35.0 & 30.5 & 4.0 & $107.0 \pm 5.93$ \\
\hline Robinia pseudoacacia & North America & 08.04 & 05.06 & 54 & --- & 30.1 & 52.5 & 7.4 & --- & $32.1 \pm 1.59$ \\
\hline Caragana turkestanica & Central Asia & 30.03 & 30.05 & 62 & 1.0 & 52.2 & 46.8 & $\begin{array}{ll}-- \\
-\end{array}$ & $\begin{array}{ll}-- \\
-\end{array}$ & $26.4 \pm 1.17$ \\
\hline
\end{tabular}




\begin{tabular}{|c|c|c|c|c|c|c|c|c|c|}
\hline \multirow{3}{*}{ Species } & \multirow{3}{*}{$\begin{array}{c}\text { Geographical } \\
\text { origins }\end{array}$} & \multicolumn{3}{|c|}{ Growth of sprouts } & \multicolumn{5}{|c|}{ Gain } \\
\hline & & \multirow{2}{*}{$\begin{array}{l}\text { begin- } \\
\text { ning }\end{array}$} & \multirow[b]{2}{*}{ end } & \multirow{2}{*}{$\begin{array}{l}\text { long, } \\
\text { days }\end{array}$} & \multicolumn{4}{|c|}{ monthly, \% } & \multirow{2}{*}{$\begin{array}{c}\text { Annual, } \\
\mathrm{cm}\end{array}$} \\
\hline & & & & & III & & V & VI & \\
\hline Acer truncatum & East Asia & 30.03 & 31.05 & 63 & 2.1 & 52.4 & 45.5 & $\begin{array}{ll}-- \\
-\end{array}$ & $21.5 \pm 1.40$ \\
\hline A. campestre & Europe & 28.03 & 10.05 & 44 & 5.5 & 86.4 & 8.1 & $\begin{array}{ll}-- \\
-\end{array}$ & $20.2 \pm 1.26$ \\
\hline A. franchetii & East Asia & 25.03 & 15.05 & 52 & 7.3 & 60.2 & 32.5 & --- & $22.9 \pm 1.41$ \\
\hline A velutinum & $\begin{array}{l}\text { Crimea, } \\
\text { Caucasus }\end{array}$ & 22.03 & 15.06 & $48+18=66$ & 11.3 & 59.2 & 9.5 & 20.3 & $34.8 \pm 2.34$ \\
\hline A. semenovii & Central Asia & 01.04 & 27.05 & 57 & --- & 61.7 & 38.3 & --- & $17.1 \pm 1.03$ \\
\hline A. ginnala & Far East & 15.03 & 11.05 & 58 & 39.7 & 53.5 & 6.8 & --- & $19.2 \pm 0.96$ \\
\hline A. ukurunduense & Far East & 17.03 & 08.05 & 53 & 32.5 & 62.0 & 5.5 & $\begin{array}{ll}-- \\
\end{array}$ & $27.2 \pm 1.59$ \\
\hline A. nigrum & North America & 16.03 & 08.05 & 54 & 15.0 & 70.4 & 14.6 & & $19.4 \pm 1.20$ \\
\hline A. saccharinum & North America & 21.03 & 10.05 & 51 & 19.5 & 71.6 & 8.9 & $\begin{array}{ll}-- \\
\end{array}$ & $6.75 \pm 0.49$ \\
\hline A. negundo & North America & 18.03 & 30.04 & 44 & 32.5 & 67.5 & --- & --- & $26.3 \pm 2.78$ \\
\hline
\end{tabular}

Table 4. Growth of lateral sprouts of members of family Oleaceae Lindl.

\begin{tabular}{|c|c|c|c|c|c|c|c|c|c|}
\hline \multirow[b]{3}{*}{ Species } & \multirow[b]{3}{*}{ Geographical origins } & \multicolumn{3}{|c|}{ Growth of sprouts } & \multicolumn{5}{|c|}{ Gain } \\
\hline & & \multirow[b]{2}{*}{ beginning } & \multirow[b]{2}{*}{ end } & \multirow{2}{*}{$\begin{array}{l}\text { long, } \\
\text { days }\end{array}$} & \multicolumn{4}{|c|}{ monthly, \% } & \multirow{2}{*}{$\begin{array}{c}\text { Annual, } \\
\mathrm{cm}\end{array}$} \\
\hline & & & & & III & & $\mathrm{V}$ & VI & \\
\hline $\begin{array}{c}\text { Fraxinus } \\
\text { rhynchophylla }\end{array}$ & Far East & 21.03 & 30.04 & 41 & 24.3 & 75.7 & --- & --- & $23.0 \pm 1.69$ \\
\hline F. americana & North America & 27.03 & 05.05 & 40 & 10.5 & 81.0 & $\begin{array}{ll}-- \\
-\end{array}$ & $\begin{array}{ll}-- \\
-1\end{array}$ & $26.5 \pm 1.94$ \\
\hline F. pennsylvanica & North America & 27.03 & 30.04 & 35 & 14.0 & 86.0 & --- & --- & $21.3 \pm 1.78$ \\
\hline F. velutina & North America & 05.04 & 15.05 & 41 & --- & 70.3 & 29.7 & --- & $27.5 \pm 1.91$ \\
\hline F. excelsior & Europe & 13.03 & 30.04 & 49 & 38.2 & 61.8 & --- & --- & $32.0 \pm 2.70$ \\
\hline F. angustifolia & Crimea, Caucasus & 15.03 & 30.04 & 47 & 31.5 & 68.5 & --- & --- & $24.2 \pm 1.73$ \\
\hline F. sogdiana & Central Asia & 27.03 & 20.05 & 55 & 7.3 & 65.0 & 27.7 & --- & $42.4 \pm 3.92$ \\
\hline $\begin{array}{l}\text { Ligustrum } \\
\text { lucidum }\end{array}$ & Far East & 04.04 & 15.05 & 42 & --- & 74.0 & 26.0 & --- & $20.5 \pm 2.14$ \\
\hline L. ibota & Far East & 10.03 & 05.06 & 87 & 22.5 & 36.0 & 38.3 & 3.2 & $34.0 \pm 2.62$ \\
\hline L. vulgare & Europe & 15.03 & 15.06 & 93 & 16.4 & 43.6 & 37.5 & 11.5 & $42.3 \pm 3.03$ \\
\hline
\end{tabular}

